\title{
SOME EARLY NIGERIAN DOCTORS AND THEIR CONTRIBUTION TO MODERN MEDICINE IN WEST AFRICA
}

by

\section{ADELOLA ADELOYE*}

To THE medical historian two roads at the University of Ibadan, Nigeria, would excite a good deal of interest. One is the Africanus Horton Road which leads to the Computer Centre, and the other is Sapara Road along which lies the Department of Nursing. Africanus Horton, together with his colleague, William Davies, were the first Nigerians to qualify as medical doctors ${ }^{1}$ when they simultaneously gained the M.R.C.S. of England at King's College, London, in 1858. On the other hand, Oguntola Sapara, who obtained the L.R.C.P. and S. of Edinburgh in 1895, was the last and eighth Nigerian to qualify in medicine in the nineteenth century. Between 1858 and 1895, five other Nigerians graduated in medicine, namely Nathaniel King (1874), Obadiah Johnson (1884), John Randle (1888), Orisadipe Obasa (1891) and Akinsiku Leigh-Sodipe (1892).

This paper briefly sketches the life histories of these illustrious nineteenth-century Nigerian doctors and the contributions which they made as pioneer physicians to the practice of modern medicine in West Africa.

After completing their studies at King's College, London, William Broughton Davies and James Africanus Beale Horton left England for Scotland where they obtained the M.D.; Davies, in October 1858 by examination from the University of St. Andrews, ${ }^{2}$ and Horton by a thesis from Edinburgh University in August 1859. ${ }^{3}$ In September 1859, Davies and Horton were commissioned in the British Army as Staff Assistant Surgeons for services in West Africa. Until their retirement some twenty years later, they served most of their time in the Gold Coast (now Ghana), and some time in Sierra Leone. The first Nigerian to practise modern medicine in his own country was Nathaniel King, who graduated from King's College, London, in 1874. ${ }^{4}$ He thereafter studied in Edinburgh before returning to Lagos to serve as the medical attendant to the agents of the Church Missionary Society.

Although Dr. King occasionally acted as locum at the Colonial Hospital of Lagos, the first Nigerian "Colonial surgeons" in that hospital were Obadiah Johnson and John Randle who were both brought into the colonial medical service of Lagos in 1889 by Governor Moloney. ${ }^{5}$ After he became M.R.C.S. of England at King's College, London, in 1884, Johnson went to Edinburgh and obtained the M.B., C.M. in 1886. While in Scotland, he became acquainted with a fellow Nigerian, John Randle, who had entered Edinburgh University in 1884 and later graduated M.B., C.M. in 1888.

*Professor of Neurological Surgery, Department of Surgery, University of Ibadan, Nigeria.

Medical History, 1974, vol. 18. 


\section{A. Adeloye}

Dr. Leigh-Sodipe was unique among his peers. Born in Lagos, he obtained his qualifying and postgraduate degrees from the University of Durham, and he was the first Nigerian doctor whose name had an African ring about it as an index of the national consciousness that was emerging in West Africa towards the end of the nineteenth century. ${ }^{6}$ Before long, wholesale Africanization of names became fashionable among the new West African élite which included our pioneer physicians. Thus, Dr. Orisadipe Obasa was George Stone Smith, ${ }^{7}$ and Dr. Oguntola Sapara was Alexander Williams ${ }^{6}$ when they were medical students in the United Kingdom.

The different phases of the evolution of medical education among West Africans during the second half of the nineteenth century are exemplified by the careers of all these Nigerians. First, the phenomenally high mortality among Europeans who came to West Africa forced the British Army to train West Africans as doctors for services in their own countries, with the Church Missionary Society superintending the selection of students. Davies and Horton were the first - and paradoxically the lastwho were trained under that scheme. King's College, London, an institution with a strong religious flavour, was naturally favoured by the Church Missionary Society, and as we have seen, enrolled the first four of our eight pioneers. When the Army abdicated its role for the training of West African doctors to the Church Missionary Society, King, and then Johnson, were sent to King's College, London. Finally, before the end of the nineteenth century, individual "medical-student-adventurers" emerged. Randle, Leigh-Sodipe, Obasa and Sapara went to the United Kingdom, without missionary or government subsidy, to seek their fortunes in different medical schools. Regardless of the origins of these pioneer medical students, most of them completed their studies in Scotland. All, except Obasa and Leigh-Sodipe, passed through the Scottish medical schools, where they, and a host of Nigerians in the early part of the twentieth century, finished their professional medical training.

When these early medical practitioners returned to West Africa they encountered the traditional medicine-men who had held sway in the healing craft for generations. Those medicine-men were not all quacks; indeed a measure of specialization was discernible in their practice as "certain of them profess to treat fevers, others dropsy, others are alienists". ${ }^{8}$ But they had no hospitals;" their pharmacopoeia was an amalgam of herbs, amulets and other ingredients, too many and too recondite to recount, and their concept of aetiology differed radically from that of young doctors fresh from medical schools in the United Kingdom. The reaction of the medical scientist to such a situation was well reflected in the scientific publications of Horton, Johnson, Randle, Leigh-Sodipe and Sapara. Davies, King and Obasa, whom we shall discuss first, left no specific medical writings, and their contributions hence lay solely in the services they rendered to make modern medicine a reality in nineteenth-century West Africa.

\section{DR. WILLIAM BROUGHTON DAVIES}

William Davies was born of Yoruba parents in Wellington, Sierra Leone, on 25 October 1833. From the village school in Wellington, he entered Fourah Bay Institute of Freetown in 1850 and trained as a catechist in preparation for a career in the ministry. When the Church Missionary Society wanted three able West African 


\section{Some early Nigerian doctors}

youngsters to be trained in England as doctors for services in the British Army, the choice fell on Davies, Horton and one Samuel Campbell, who, on reaching England, developed severe bronchitis which led to his return to his native Sierra Leone and to an early demise. ${ }^{10}$ After the successful completion of their medical education in the United Kingdom, Davies and Horton were appointed Staff Assistant Surgeons in the Army medical services. They arrived at Cape Coast in October 1859 and officially commenced work at "the usual salary of 5s. per diem"11 from 1 December 1859. By contrast with the versatile and prolific Horton, Davies was extremely quiet during his twenty-two years in the Army and afterwards. A stately gentleman with the courtly manner of the Victorian age, Davies wrote, as far as is known, only the necessary official letters. He passed his retirement in the happy company of his family, and died in Sierra Leone on 13 January 1906. By the good example of his successful career in the Army, from which he and Horton retired as Surgeon-Majors, Davies vindicated his race, downtrodden by the iniquitous slavery, from the prejudices and low expectations of the time.

\section{DR. NATHANIEL KING}

Nathaniel King was born of Yoruba parents in Hastings, Sierra Leone, on 14 July 1847. His father, Rev. Thomas King, together with Ajayi Crowther, translated several catechisms and portions of the Bible into Nigerian dialects. The transfer of Thomas King from Sierra Leone to the Yoruba mission in Nigeria in 1850 allowed Nathaniel to gain early association with his country of origin. Very early in life, he showed his intellectual brilliance and caught the attention of A. A. Harrison, M.D. (Cantab), the missionary doctor who, under the impetus of Rev. Henry Venn, started a "medical school" at the Church Missionary Society Theological Institute at Abeokuta in 1861. Nathaniel King was one of the four "promising native youths"12 selected to be trained by Dr. Harrison. They used four copies of Hooper's Physician's vade mecum, supplied by the parent committee of the Church Missionary Society at Salisbury Square, London. ${ }^{13}$ Dr. Harrison taught anatomy, physiology, chemistry, botany, materia medica, surveying, and a snippet of Euclid and "only got as far as the fifth proposition". ${ }^{12}$

The Abeokuka experimental medical school was unfortunately short-lived. One student was dismissed, two were sent to teach in Lagos Schools, and Nathaniel King, who had made encouraging progress, was the sole survivor. He became personal assistant to Dr. Harrison. With the latter's death in 1864, the first attempt at medical education in a Nigerian institution was prematurely concluded.

For Nathaniel King, it was not the end. The Church Missionary Society sent him to Sierra Leone in 1866 to prepare for a career in medicine, anticipating his future admission into the Army medical service like Horton and Davies before him. In 1871, he entered King's College, London, and gained the M.R.C.S. in 1874. He obtained from Edinburgh the M.B., C.M. in 1876 and the M.D. three years later. King was back in Lagos in 1878 where he gave his services to the Church Missionary Society for "fifty pounds per annum"14 until January 1882 when his annual salary was increased to seventy-five pounds. A highly talented and popular man, his wholehearted service to his patients and his charming personality enabled him to break 


\section{A. Adeloye}

the confines of colour and discrimination so that he became consulting physician to most of the European firms in Lagos.

An early death on 12 June 1884 cut short his promising career. He had been in the vanguard of the efforts which led to the improvement in sanitation in old Lagos. His profound literary and scientific knowledge, comparable to that of Horton, was acknowledged by his contemporaries. Apart from speculations that he was collecting material for a future book on science at the time of his death, ${ }^{15}$ there is nothing substantial to show for the erudition of Nathaniel King.

\section{DR. ORISADIPE OBASA}

Prince Obasa was born in Freetown, Sierra Leone, in January 1863. His father was the son of Elekole of Ikole-Ekiti and his mother came from the royal family of Akija of Ikija in Abeokuta. Obasa came to Lagos in his youth and entered the newly opened Wesleyan Boys High School, Lagos, in 1878 as the Senior Foundation Scholar. At the end of 1879 when Governor Moloney distributed the school prizes, Obasa topped the list of the sixteen prize-winners. ${ }^{7}$ In 1883 , he was sent to England by his parents to study medicine. He first entered King's College, Taunton, where, once more, he was frequently at the top of his class. Thereafter, Obasa enrolled as a medical student at St. Thomas's Hospital Medical School, London, where he gained the M.R.C.S. and the L.R.C.P. in 1891 .

He returned to Lagos in 1892 to commence private practice. Towards the end of the nineteenth century, Obasa accompanied the contingent of the Lagos Constabulary to the Gold Coast (Ghana) during the Ashanti War. He won a medal for his outstanding services on that expedition, an achievement which helped him to gain a position as Assistant Colonial Surgeon in the medical services of Lagos in $1900 .{ }^{16}$

Dr. Obasa took a leading part in public health campaigns in Lagos colony and in other districts of Southern Nigeria. His most notable participation was his special visit in 1903 to Ekiti, the district of his origin, in connexion with the smallpox vaccination scheme launched by Governor Macgregor. ${ }^{7}$ Obasa's medical reports contained some clinical observations which are relevant today. Thus, he found yaws peculiar to the Ijebus, ankylostomiasis the commonest parasitic infestation in Southern Nigeria, and in Ikorodu and Shagamu he noticed that inguinal hernias generally occurred on the right - "left inguinal hernia is an exception".17

Obasa's stay in the colonial medical service was short. In 1902, he had married Charlotte Olajumoke, the daughter of Richard Blaize, a wealthy merchant of old Lagos. His wife could not tolerate the long absences of her husband. Money was plentiful in the family; Richard Blaize had given the Obasas a comfortable house in Lagos as a wedding present, and with his passionate relish for public life, it took very little to persuade Dr. Obasa to resign his appointment as colonial surgeon in 1904.

Obasa at once resumed his private medical practice, but his paramount preoccupation was politics. With his bold articulate tongue and powerful pen, with the social advantages of his marriage connexion, with his own capacity for work and for friendship, Obasa launched himself into the political life of Lagos, set, so it then appeared, for a magnificent success. His opportunity came with the water-rate agitation, to sustain which he and Dr. Randle formed the People's Union in 1908, 


\section{Some early Nigerian doctors}

with Randle as president and Obasa as secretary. This was the first political party in Nigeria. ${ }^{18}$ For almost a decade, they kept alive the people's opposition to the waterrate levy, during which, in slow degrees, the agitation burnt itself out until its final collapse in 1916. Obasa, Randle and the People's Union fell out of favour with the electorate; even a change of name to Reform Club did not revive the declining Union. The final blow to Obasa's party was the appearance on the political stage of Lagos of the Nigerian Democratic Party, a new and more virile political party, led by Herbert Macaulay. By dint of individual merit, Obasa nevertheless became a nominated member of the Nigerian Legislative Council in 1921 and served creditably on several committees. However, the moment of truth came in September 1923, when the first parliamentary elections to the Legislative Council were held. ${ }^{19}$ Obasa was defeated.

With the death of Randle in 1928, Obasa became the accredited leader of the People's Union. Two years earlier, he had contracted Parkinson's disease, which progressively incapacitated him. After fourteen empty years, Obasa died on 15 April 1940 at his residence in Lagos, the last of the eight Nigerians who qualified in medicine in the nineteenth century.

\section{DR. JAMES BEALE AFRICANUS HORTON}

In terms of specific writings on medical subjects, the most outstanding contribution was made by Africanus Horton. He was born of Ibo parents in the village of Gloucester, Sierra Leone, on 1 June 1835 . In an age of phenomenally high infant mortality, he was the lone survivor of eight children. ${ }^{20} \mathrm{He}$ had his preliminary education at the village school in Gloucester under Rev. Beale. When, in 1847, he entered the Sierra Leone Grammar School, the curtain was raised in the drama of his memorable career. His studies included Latin, Greek, and English literature, which provided the classical education which was to feature subsequently in his prolific prose. Horton went on to Fourah Bay Institute (later called Fourah Bay College) where, like William Davies before him, he passed two years with the intention of training for the ministry. When in 1855 the British government wanted to train promising West Africans for medical posts in the Army, Horton, who had by then left his mark as a potential intellectual, was chosen and sent to London.

Horton graduated at King's College in 1858 after an eminently successful undergraduate career. Dr. R. Jelf, D.D., the principal, in a testimonial commended "the excellent conduct and diligence of Dr. James B. Horton" during his studentship when "he gained the prize for surgery and five certificates of honor [sic] in different branches of medical education". ${ }^{21}$ On graduation, the principal and professors recommended to the Council Horton's election to the Associateship of the college, "a distinction which always implies not only proficiency in studies, but also an unimpeachable academic character". ${ }^{21}$

On 19 October 1858, Horton matriculated at Edinburgh University. In March 1859 , he submitted his thesis entitled "The medical topography of the West Coast of Africa, with sketches of its botany" for the M.D. which he gained with commendation on 1 August 1859. On the title-page he referred to himself as a "native of West Africa" and christened himself "Africanus". Many scholars of African nationalism 


\section{A. Adeloye}

hailed this new name as evidence of the political awakening of Horton. ${ }^{3}$ That was probably correct. It is also possible that the erudite Horton took his cue from the practice of older scholars who often latinized their names on gaining eminence. Thus Jacques Dubois, the French anatomist, became Jacobus Sylvius and his illustrious pupil, Andrew Wesel of Brussels, later christened himself Andreas Vesalius Bruxellensis. ${ }^{22}$

Horton retired from the British Army in West Africa in 1880 as a Surgeon Major. Thereafter, he took up banking, and against manifold odds, succeeded in founding his Commercial Bank of West Africa in December 1882. ${ }^{23} \mathrm{He}$ died in Sierra Leone in October 1883 from a severe attack of erysipelas. ${ }^{24}$

Horton's first major medical publication was his M.D. thesis. His theme was to familiarize the doctor seeking medical practice in West Africa with the climatic conditions of the various countries from the archipelago of the Spanish Canaries to the island of Fernando Po. He cited examples of the medical craft among West Africans, an instance of which was the practice of circumcision among the Gallinas. His detailed description of the mosquito betrayed that there was a suspicion of a possible link between that "sanguinary gnat" and malaria fever. Horton wrote at considerable length and with authority on the botany of West Africa and mentioned some plants which were used in the various countries for therapeutic purposes: the bark of the mangrove tree as a febrifuge in Gambia, the leaves of the castor oil plant (Ricinus africanus) as a sialogogue among the women of Cape de Verde Islands, and in Sierra Leone, the antiemetic Citrus medicae, the unripe pawpaw (Carica papaya) as a vermifuge, and many others which were still unknown "for want of able investigators". ${ }^{25}$

Horton's erudition, his mastery of narrative prose and his thorough and wide classical education were evident in this work and his subsequent writings. The moving, almost nostalgic, picture which Horton painted of Freetown, his "seeming paradise" could be compared to Stevenson's description of Edinburgh, his "Athens of the North". ${ }^{26}$ His graphic rendering of the meteorological phenomena of West Africa is also a joy to read, despite one's disagreement with the four seasons which he described for tropical West Africa where we only have two - the dry and the wet.

He touched on environmental hygiene, which has always been an important aspect of modern medicine in Africa. Horton advised the inhabitants of Freetown to interrupt their perpetual toil by an annual holiday in the healthy sea district of Sierra Leone. He gave hints for the preservation of health in the tropics, a theme which echoed throughout his subsequent medical writings. His lengthy unpublished treatise on tropical diseases, which he sent to the London headquarters of the Church Missionary Society in 1861 was entirely devoted to these hints. ${ }^{27}$

In 1867, Horton wrote his Physical and medical climate and meteorology of West Coast of Africa. With hints to Europeans for the preservation of health in the tropics. This book expanded some of the meteorological and geographical peculiarities of West Africa which Horton touched upon in his M.D. thesis in 1859, and included the experiences of his six years as an army doctor in West Africa. The work was a great and immediate success. Horton's passionate plea for improvement in sanitation in Freetown gained the sympathetic ears of the colonial government, ${ }^{28}$ which almost at once instituted a Board of Health for the first time in the history of Sierra Leone. 


\section{Some early Nigerian doctors}

In 1868, Horton wrote an elegant monograph on guinea worm infestation, based on his experience with this disease in Ghana. Once more, he drew on his profound knowledge of geology to explain the regional distribution of the disease. It was in the treatment of this disease that Horton made his unique contribution. Apart from the time-honoured extraction of the worm by rolling it round a piece of stick (or a crow-quill which Horton used), he recommended the use of the tincture of assafoetida (an oleo-gum resin made from the roots and rhizome of Ferula assafoetida) which, taken orally, rapidly destroyed the parasite, with quick relief of pain. Horton came across this effective remedy through its good effect among Ghanaians, an experience comparable to that of William Withering of Birmingham, England, who introduced digitalis leaves into the treatment of heart failure through his contact with the gypsies of Shropshire. ${ }^{29}$ On the good effects of assafoetida on a family afflicted with guinea worm, Horton wrote: "After using it for some time, they were perfectly freed from it, and for upwards of nearly fifteen years never had another attack. . . . After the use of assafoetida, I have in many cases seen it [the worm] coiled under the skin, and from its difficulty of undergoing putrefaction in the human system, it remains there for months or even years, without causing the least disturbance, giving to the touch the feeling of a whipcord"' ${ }^{30}$ This enthusiastic claim is still to be confirmed.

Horton's greatest work was his The diseases of tropical climates and their treatment which was published in 1874. (He read the galley proofs while he was engaged in the Ashanti war of 1873.) The work inevitably represented nineteenth-century concepts of diseases and their management, and miasmatic influences which emanated from decomposing matter were incriminated for producing almost every epidemic disease. ${ }^{29}$ The therapeutic hotch-potch of the time, most of which is now obsolete, ranged from the use of tinctures to blood-letting with purgation as an adjuvant in practically every case. Horton won credit, however, for his superb skill and artistry as a writer, and he supplied the relevant historical background and details of the diseases.

The book had three parts. Part I dealt with fevers, Part II with disorders of the gastrointestinal tract and its related viscera, and Part III with generalized affections, anaemia, nutritional deficiencies, chronic rheumatism and parasitic infestations. There was an appendix on environmental hygiene in which Horton spelled out his usual hints for the preservation of health in the tropics, from detailed suggestions on how to dress to what to drink. The second edition which came out in 1879 was extended by a twenty-seven-page appendix on materia medica.

From the end of the nineteenth century, the great advances in medical science rendered much of Horton's work obsolete. Unfortunately his early death robbed him of the opportunity to witness these changes and to include them in his monograph. Another revised edition would probably have saved the book from the obscurity into which it has fallen. Two sections of the book, however, deserve special mention, on account of their anticipation of some disease entities which have become topical today.

In the chapter on splenic enlargement, ${ }^{31}$ Horton described in surprising detail some features of chronic splenomegaly which are receiving more attention in tropical medicine today. He attributed the primary or idiopathic variety of tropical splenomegaly to residence in malarious countries, a concept which is now accepted as the 


\title{
A. Adeloye
}

aetiological basis of the tropical splenomegaly syndrome. ${ }^{32,33}$ The best therapy which Horton recommended was a combination of cod liver oil, quinine and iodide of iron. The mixture could not be given for a long time probably because of the nauseating cod liver oil and the irritating quinine. But Horton had highlighted the beneficial role of antimalarial agents in splenomegaly; today antimalarial drugs which are more powerful and less toxic than quinine have become the sheet-anchor of treatment. ${ }^{34,35}$

What Horton described in the chapter on "Chronic rheumatism"36 was almost certainly sickle cell disease, a haemoglobinopathy which is common in West Africa. Horton gathered his experience from the Gold Coast (Ghana) where "long before Herrick (1910) described sickle cell anaemia. . . . Ghanaians recognized the disease as a dangerous hereditary syndrome."37 To Horton, therefore, belongs the credit for one of the earliest descriptions of this disease. ${ }^{38}$

An account of Horton's contribution to the advancement of modern medicine in West Africa would be incomplete without reference to his advocacy of the establishment of a medical school in West Africa for the training of Africans. In 1861, he forwarded to the War Office in London his classic letter in which he pleaded that:

\begin{abstract}
a small Government Medical Establishment be made at Sierra Leone and that certain young men, not above the age of 20 , who have made some proficiency in Latin, Greek and Mathematics be selected from these in the CMS college or schools from the four colonies and settlements of West-Africa-Gambia, Sierra Leone, Lagos and Cape Coast ... They should be prepared in the preliminaries of medicine, anatomy, physiology, chemistry, botany (of Africa) natural history, hospital practice and pharmacy, for a certain period, from one year and a half to two years.
\end{abstract}

This recommendation was turned down. In 1871 he next advocated a West African University, if Africans must advance their education, which was then circumscribed "to the study of only scripture, history, geography, grammar, and arithmetic". ${ }^{40}$ He argued that such an institution was needed to cater for the study of botany, mineralogy, physiology, chemistry, engineering, architecture, "and of other kindred subjects which are the fundamental sciences which elevate the mind and develop the intellectual growth of any race". 40

A West African University did not come into existence then, but the Fourah Bay College of Sierra Leone was affiliated to the University of Durham in 1876. It is of special interest to us that one of the first three students to gain the Bachelor of Arts degree of Durham at Fourah Bay College was Obadiah Johnson who went on to qualify in medicine.

\section{DR. OBADIAH JOHNSON}

A personification of the subtle wisdom and geniality of the Oyos of Western Nigeria, Obadiah Johnson came from a family distinguished for its ecclesiastical, linguistic and literary excellence. ${ }^{41}$ The fourth child in a family of seven, Obadiah was born at Hastings, Sierra Leone on 29 June 1849. His educational career which began in 1855 at the Day School in Hastings was continued in Nigeria in 1858 as a result of the transfer of his father to Ibadan. After a spell at Kudeti, Ibadan, Obadiah Johnson entered Faji Day School, Lagos, in 1864 where his brother, Nathaniel, was a school-teacher. Obadiah left Faji in 1868 and became apprenticed to a Lagos 


\section{Some early Nigerian doctors}

carpenter. After two years he returned to Sierra Leone to study at the Grammar School in Freetown from where he entered Fourah Bay College in 1877. When that college became affiliated to Durham University in 1876, two annual open scholarships were created to encourage the best students to go to Fourah Bay. Obadiah Johnson, who topped the list of the candidates in a competitive examination, went on to pass the B.A. degree in 1879.42

Johnson, like Davies, Horton and King, studied medicine at King's College, London. A student of exceptional brilliance, he brought off the remarkable feat of winning "all the prizes in science". ${ }^{22} \mathrm{He}$ gained the M.R.C.S. and the L.S.A. in April 1884. After graduation, like Horton before him, Johnson was elected by the Council to the Associateship of King's College. He spent the next two years in Edinburgh, and returned to Lagos in 1886.

Johnson spent a year in private practice in Lagos, and another as medical officer of health in Sherbo, Sierra Leone. He then returned to Lagos at the invitation of Governor Moloney, who had wanted to bring an African into the colonial medical service of Lagos. Dr. Johnson, with his glowing testimonials and many diplomas seemed the right man for the position. The infamous Adeola scandal of June 1888, ${ }^{5}$ when Adeola, a patient, died from neglect at the Lagos Colonial Hospital, merely catalysed the administrative changes in the colonial medical service. In 1889 Johnson was appointed an Assistant Colonial Surgeon in Lagos.

The high hopes that Johnson had entertained for a life-long career in the medical service were stultified by the unhealthy racial prejudices of the time. In July 1897, after suffering these with dignity and resignation, Johnson left, and with his characteristic gentlemanly disposition, gave "no reason for the step which he has taken".48 In 1901, at the instance of Sir William Macgregor, M.D., LL.D., G.C.M.G., Johnson was brought into the Legislative Council where he served for thirteen years which spanned the tenure of gubernatorial office of Macgregor, Egerton and Lugard. With his perspicacity, Johnson was largely responsible for the great strides which were made in sanitation and environmental health in Lagos during his days in the Legislative Council. In his last years in the Council, the erudite Johnson came into his own. His opinion became invaluable and was sought by many. His voice, not usually the loudest, was often the last on many of the controversial issues. He died in September 1920, in London, where his remains were buried. Many friends mourned the loss of Obadiah Johnson - gentleman, beloved pioneer physician, shrewd legislator, devout Christian - whose speeches on all occasions, whether in the Legislative Council or at a church committee, were made memorable by their characteristic "Johnsonian sparkle" such that he was often thought "to have swallowed the dictionary of his English namesake and afterwards taken an emetic". ${ }^{44}$

Johnson wrote a thesis on "West African therapeutics" 45 in 1889 for which he was awarded the postgraduate M.D. of Edinburgh University. He described the medicine traditionally practised among West Africans "who have had no English education".45 Johnson wrote from his own experiences and from his first-hand knowledge of Sierra Leone and its neighbouring areas and more especially of Lagos and "Yoruba country" where he practised on his return from Europe. Medicine men were "botanists"; but how in spite of their lack of scientific education, they knew what 


\section{A. Adeloye}

herbs to use for particular maladies puzzled Johnson. He observed, however, that they selected a herb on account of its resemblance to the diseased part to be treated or from association of ideas in the name of the plant. Thus, for the treatment of excessive vomiting in pregnancy or of excessive foetal movement the velvet leaf (Cissampelos pareira) is used, it being known among the Yorubas as Jokoje which means "let me remain quiet, or keep quiet". Johnson remarked on the use of incantation in what he referred to as "speaking the cure". "I do not believe myself in the truth of the same", wrote Johnson, "but what I think very probable is that some few men possess the mesmeric power, and are able by means of it to bring temporary relief of pain as they have been known to do even in civilised countries". ${ }^{45}$

Johnson noted that the surgical craft of these medicine men was limited to the use of scarification marks on swellings or painful parts of the body, removal of cervical glands in the treatment of phthisis, blood-letting by cupping, and circumcision of males and females. There were stories in parts of West Africa, for which Johnson found no substantiation, of medicine men who were said to be capable of performing splenectomy as part of the therapy for malaria. The infrequent use of surgery by traditional medicine men was not because a restraining code of ethics aimed at punishing the incompetent surgeon tied their hands, ${ }^{46}$ but because, on one hand, West Africans were reluctant to lose any part of their bodies by deliberate removal, preferring deformity or even death. On the other hand, the ministering medicine men were aware of their severely limited surgical expertise. Hence, as Johnson observed, they gave the qualified modern surgeon "more eclat than they would bestow on a physician". ${ }^{45}$

Johnson was impressed by the common occurrence of multiple births among Nigerians, an observation which has been confirmed in West Africa in general.47 In the Yoruba village of Igbo-Ora in Western Nigeria, Nylander reported a twinning rate of 45 in 1000 deliveries, the highest rate on record in the world, ${ }^{48}$ compared with the 11 to 12 per 1000 reported for England and Wales. ${ }^{48}$ Johnson also mentioned that, in certain parts of the country, Nigerian women are said to be capable of making antenatal diagnosis of multiple pregnancy, a claim which is still made in contemporary times. ${ }^{49}$ The practical advantages of this ability must have been considerable among the Calabars of Southern Nigeria where twins used to be destroyed before the days of Mary Slessor. ${ }^{50}$

Special mention must be made of Johnson's efforts and contributions to the production of the History of the Yorubas. ${ }^{9}$ His love of the Yorubas, his anxiety to get his brother, Samuel's work published, and his own intrinsic scholarship, all made possible this monumental monograph on the origin and customs of the Yorubas. The original manuscript compiled by Samuel Johnson was sent to an English publisher who "lost" it. After Samuel's death in 1901, Obadiah resuscitated the manuscript from his brother's voluminous notes. In 1916, Obadiah sent the new manuscript to England, where it arrived in 1918 due to the capture during the First World War of the ship on which it was carried. Finally, the post-war scarcity of paper in England delayed publication till August 1921, nearly a year after his death.

DR. JOHN RANDLE

One of the most remarkable men in the history of modern medicine in West Africa 


\section{Some early Nigerian doctors}

was John Randle. He came from humble origins, but he overcame his disadvantages to become one of the most financially successful doctors of his era. This enigmatic pioneer physician was forever embroiled in controversies both in his private life, in his professional dealings with patients, and in his political activities. Celebrated for his unrelenting austerity and the extremes of harsh discipline, Randle never owned a car, but rode a bicyle even at the age of seventy. Yet, like Carnegie, his Will established him as a great West African philanthropist. He passionately encouraged many Africans to pursue extensive learning, yet some of his own children accused him of neglecting their basic education. At heart a believer in Africans and in the African ways of life, Randle remained in his attire and taste a Victorian. He specially ordered his food from London. Randle "loved" his patients, so much so that when they disobeyed his dietary instructions, he invoked police action to establish his medical authority. ${ }^{41}$ To his lasting credit, he was in the vanguard of the movement which led to the launching in Lagos in 1908 of its first political party, the People's Union. ${ }^{18}$ of which he remained Life President (see p. 279). When the party ran into difficulties, Randle's political image suffered severe setbacks from which he never recovered. With all the vissicitudes which would have crushed lesser men, Randle remained immutably himself - a fighter from the first to the last, ever resolute and courageous, and always aspiring not only to master his own fate but also to mould the destiny of others.

Randle was born on 1 February 1855 in Regent, a village situated at the foot of the Sugar Loaf mountains in Sierra Leone. His father, Thomas Randle, a liberated slave, came from an Oyo village in Western Nigeria, and ultimately returned to Lagos to establish a successful haberdashery trade at Aroloya. ${ }^{52}$ From the village school in Regent, John Randle went to the Grammar School in Freetown. In 1874, he enrolled as a student dispenser at the Colonial Hospital, Freetown, and qualified in 1877. Thereafter, he left for the Gold Coast where he was involved in many public health programmes, including extensive smallpox vaccination. He impressed his superiors with his unusual diligence and enthusiasm so that they helped him to achieve his ambition to study medicine. Randle was said to have saved almost every penny he had in order to finance his studies, which began at Edinburgh University in 1884, and were successfully completed in 1888 when he graduated M.B., C.M. and gained the gold medal in materia medica. ${ }^{51}$

Randle came to Lagos in December 1888 as a locum Assistant Colonial Surgeon at the Lagos Colonial Hospital in the aftermath of the Adeola scandal. Randle obtained a substantive position as an Assistant Colonial Surgeon shortly after the appointment of Obadiah Johnson. Almost at once, Randle encountered a discriminatory policy in the medical service against which he naturally and forcefully revolted. He won the support of the European Acting Colonial Surgeon, Dr. Jeans, who wondered why Randle "who passed out of Edinburgh with much credit to himself and is therefore on an equal footing as regards medical education with Europeans", ${ }^{53}$ should receive no more than half the salary of his European colleagues. It was, of course, a hopeless battle. In 1893, Randle refused to continue to do tours of duty at Ijebu Ode, where a small peace-keeping band of British troops was stationed by Governor Gilbert Carter in 1892; as a result, Randle was dismissed in September 1893.54 


\section{A. Adeloye}

By that time, Randle had established himself in the public life of Lagos. In November 1890, he married Victoria Matilda Davies, eldest daughter of the rich James Labulo Davies and of Sarah Forbes Bonetta Davies, the Yoruba slave girl who was adopted and educated at the personal expense of Queen Victoria. ${ }^{55}$ The name Victoria was given to Matilda Davies at her christening by Queen Victoria who also gave her a life-long allowance of forty pounds sterling and a "solid gold christening set" "56 which is still preserved in Lagos by Randle's son, Romanes Adewale. Maltida's wedding gown was the gift of the queen, "who kindly chose the material and before sending the gown to be fitted on, she had it made up for her own and her family's inspection and then sent the bride a very pretty message to say they hoped she would think it as charming as they did". ${ }^{57}$

A man of enormous energy, Randle quickly established an extensive private practice in Lagos, not only among the indigenous population, but also among the agents of several European firms. After he quitted the colonial medical service, there was more time for him to indulge his political interests, and he soon became one of the most "authoritative exponents of native public opinion in Lagos". ${ }^{18}$ In 1899, Randle had a brief taste of politics when Governor Sir William Macgregor brought him into the Legislative Council as a "provisional member". Shortly after the turn of the century, Randle launched his Union to champion the cause of the people of Lagos (see pp. 278-279).

Although he did not compose a medical thesis, Randle contributed to modern medicine within the limitations of his crowded life. Governor Gilbert Carter, in one of his most trenchant reports to the Colonial Office, London, in 1892, in which he advocated the dismissal of the pugnacious Randle from the medical service, magnanimously acclaimed Randle's success in the treatment of yellow fever. ${ }^{58} \mathrm{Un}$ fortunately, there is no available record of Randle's writing on fevers. Two subjects on which he wrote were the "Treatment of guineaworm"59 and the incidence of "Cancer among the African Creoles"."

His article on guineaworm was a review of the various current methods of treatment, with emphasis on those which he found to be effective. He unequivocally discouraged the use of assafoetida, in sharp contrast to the strong recommendation of Horton. ${ }^{30}$ Randle, during twenty years of observation, found that not the slightest good was done by assafoetida in guineaworm infestation, and hence he recommended that it should be reserved for treating psychiatric disorders. ${ }^{61}$ As far as I know, there is no mention of the use of assafoetida in the treatment of guineaworm besides the contradictory writings of Horton and Randle. It would be worthwhile to attempt to resolve this controversy.

Randle recommended a combination of the use of poultices, constant daily traction and incision of any accompanying abscesses "using a Paget's knife".59 Efficient drug treatment of guineaworm is now available, but the principles of treatment enunciated by Randle in 1894 are still true today.

Randle's article on the incidence of cancer among Africans was his response to a paper by Dr. W. Renner on the incidence of malignant diseases among the Africans attending the Colonial Hospital of Freetown. ${ }^{62}$ Renner, an African Creole "colonial surgeon" who later africanized his name to Awunor-Renner, ${ }^{63}$ noted that in the last 


\section{Some early Nigerian doctors}

thirty years of the nineteenth century there were twenty cases of malignant diseases where, from 1901 to 1909 , he encountered twenty-two cases. Although consciously refraining from making definite conclusions, Renner implied that the observed increase of malignant diseases among the Creoles arose from the influence of civilization which altered their traditional mode of living. Randle's article challenged the validity of Renner's statistics and gave another explanation for Renner's observation. Randle cited examples of malignant diseases which he encountered among the Ijebus in Southern Nigeria, cases which would not have been known had he not been posted to work there. His reason for the low incidence of cancer which Renner reported towards the end of the nineteenth century was because the Africans did not come to hospital.

Since the pioneer publications of Renner and Randle, a spate of articles has appeared on the incidence of malignant diseases in the African. Randle's suggestion about the reported infrequency of cancer among Africans complemented, but did not negate Renner's thesis of the influence of environment and way of life. The events of today have justified both reasons. It has been found recently that cancer is almost as common among the American Negroes as it is among the American whites. ${ }^{64}$ Also, with the more universal acceptance of modern medicine and patronage of hospitals, malignant diseases in the African are showing up in greater numbers.

Randle died on 27 February $1928 .{ }^{51}$ In 1940 his remains were moved from the rear to the front of the Ikoyi cemetery in Lagos - a symbolic gesture, which recognized his achievements.

\section{DR. SODEINDE AKINSIKU LEIGH-SODIPE}

The death of Dr. Leigh-Sodipe in his thirty-sixth year made his life and career the shortest among our pioneer doctors, but not the least in terms of productivity. Like Horton and Johnson, he wrote a thesis which earned him the M.D. degree in 1897. The elder son of Consul and Mrs. Leigh, Dr. Leigh-Sodipe was born in Lagos on 29 March $1865 .{ }^{65}$ After a brilliant school career at the Church Missionary Society Grammar School, Lagos, his rich parents sent him to England in 1881 to study medicine. He qualified at the College of Medicine, Newcastle upon Tyne, by gaining the M.B. degree of Durham on 30 April $1892 .{ }^{\circ 6} \mathrm{He}$ returned to Lagos and set up in private practice, where he quickly gained friends and patients because of his winsome manner and amiable disposition. In 1893, he was godfather at the christening of Randle's son, Romanes Adewale, ${ }^{52}$ who still lives in Lagos. In 1896, Leigh-Sodipe was appointed an Assistant Colonial Surgeon, with Dr. Oguntola Sapara, in the colonial medical service of Lagos. ${ }^{67} \mathrm{He}$ served not only in Lagos, but also at Ibadan, Saki, Badagry and Epe. In 1897 he married Sabina Thomas, the only daughter of the Hon. J. J. Thomas. Unfortunately their only child died in infancy. ${ }^{68} \mathrm{Dr}$. LeighSodipe developed a malignant fever while he was at Epe in 1901, and was rushed to the medical headquarters in Lagos, where he died at the Ereko Dispensary on 15 April 1901 from a fulminating hepatic abscess. ${ }^{69}$

Leigh-Sodipe wrote his M.D. thesis on "The relationship between nature and medical treatment with special reference to Native West African methods",41 and the University of Durham conferred the degree on him in absentia on 25 September 


\section{A. Adeloye}

1897. ${ }^{70}$ If Obadiah Johnson had described the art of traditional medicine found among the indigenous West Africans, Leigh-Sodipe in a rambling philosophical manner had advocated the Hunterian spirit of scientific inquiry in the analysis of herbal medicine. Leigh-Sodipe reasoned that the "mere knowledge or the simple fact of seeing and becoming acquainted with a thing is not science; to see, find out or attempt to find out and know the rationale of cause and effect are the principles of science". ${ }^{41} \mathrm{He}$ incriminated as aetiological factors in West African diseases the stresses of life, the morbid influences of climate and, as if to echo the postulate of Dr. William Renner, ${ }^{62}$ the adoption of western civilization which interfered with "former usages and customs of life and general environment". ${ }^{41}$ He predicted that as intercommunication increased, the diseases of one region would inevitably extend to another. He raised our hopes that "whenever a disease is indigenous to any soil, the remedy is always at hand or not very far off". ${ }^{41}$ Finally, he stressed the importance of preventive measures. "It is better to prevent than to cure","11 Leigh-Sodipe advocated, a policy which brings man back to the observation of the fundamental laws of Nature and which is a very much needed aspect of modern medicine today in West Africa.

\section{DR. OGUNTOLA ODUNBAKU SAPARA}

By far the most colourful of our pioneers of modern medicine in Nigeria was Dr. Sapara, who was born in Freetown, Sierra Leone, on 9 June 1861. His father, a liberated slave, came originally from Ilesha in Western Nigeria, and his mother, Nancy, from Egbaland. His sister, Mrs. Clementina Foresythe, died in labour in 1877, and it is said that it was that disaster that led Sapara to study medicine, particularly midwifery. ${ }^{21}$ His brother, Christopher, became the illustrious Honourable Sapara Williams - jurist, advocate, legislator, politician and the legendary leader of the bar in Lagos. ${ }^{72}$

Sapara was educated at the Buxton Memorial Day School and the Wesleyan Boys' High School in Freetown. With the return of his family to Lagos in 1876, Sapara attended the Lagos Church Missionary Society Grammar School until 1878, and became apprenticed to a Lagos printer early in 1879. A medical career was his objective, hence he abandoned his new trade and entered the Colonial Hospital as an unpaid assistant dispenser under Dr. J. W. Rowland. He left for England and entered St. Thomas's Hospital Medical School, London, in 1888. He gained honours in midwifery and thereafter went to Scotland where, in 1895, he obtained the L.R.C.P. and L.R.C.S. of Edinburgh, the L.F.P.S. of Glasgow and was elected a Fellow of the Royal Institute of Health. Almost immediately Sapara returned to Lagos, where in January 1896 he was appointed an Assistant Colonial Surgeon in the medical department of Lagos colony and served in many stations without interruption until his retirement in January 1928. He died at his home in Lagos in June 1935.

During his long and fruitful career, Sapara made vital contributions to social and preventive medicine in all the medical stations in Southern Nigeria. Thus, he initiated the fight against the "filth and jungle" of Ebute Metta in 1900. He organized the building of a first public dispensary at Saki in 1901. In 1918 at a conference convened to fight the alarming rise in the incidence of tuberculosis in Lagos, the most valuable contribution was the joint paper by J. M. Dalziel and Oguntola Sapara. ${ }^{73}$ The 


\section{Some early Nigerian doctors}

authors incriminated overcrowding, defective ventilation and mass ignorance, for which they prescribed corrective measures, not only to combat tuberculosis in particular, but in general to improve the environmental sanitation of Lagos. As Chairman of the Health Week Committee, Sapara led the successful fight against bubonic plague which struck Lagos in 1924. ${ }^{74}$ However, it was his outstanding role in the eradication of smallpox in Southern Nigeria that gave him pre-eminence in our history.

When Sapara took over the medical district of Epe in 1897, the village was notorious for outbreaks of smallpox. Every public health measure had failed to control the epidemics so that the villagers had resigned themselves to a scourge which sooner or later must destroy them. Sapara discovered a cult of smallpox worshippers at Epe which was alleged to be responsible for disseminating this disease. In his frustration, the intrepid Sapara resorted to the unorthodox approach of joining the cult! He got to know their modus operandi which formed the basis of his classic report of 1909. Sapara wrote in his report:

In 1897 when I took charge of Epe district, the town of Epe was known as the hotbed of small-pox epidemic. Finding that vaccination and other precautions seemed to fail, I joined the cult and having got into the mysteries I summoned the small-pox priests together, and threatened them with prosecution for disseminating the disease and used perchloride of mercury solutions. They left the town through disgust and since then, up till the time I left Epe, vaccination had scope for doing good work and then the town enjoyed an immunity from small-pox, hitherto unknown. ${ }^{75}$

Governor McCallum lost no time in implementing the recommendations of Sapara's smallpox report. The "Witchcraft and Juju Ordinance" worship of smallpox punishable by imprisonment. It led to immediate and substantial decrease in smallpox outbreaks, and was a personal triumph for Sapara.

He spent the latter part of his time in the colonial service at the Massey Street Dispensary in Lagos. On account of its central position, the dispensary served a large portion of Lagos. Sapara successfully convinced the government to convert the dispensary into a hospital, the Massey Street Hospital, which was opened by Governor Graeme Thomson in 1926. ${ }^{77}$ In commemoration of Sapara's services, the road behind the hospital was named Sapara Avenue; after his death, a plaque was erected in the hospital to his memory by the Lagos medical practitioners.11

Sapara was in the forefront of the campaign launched at the beginning of this century by the government to reduce infant mortality in Lagos. He organized a society which had as its sole mission the scientific training of African midwives. He gave public lectures to stimulate the interest of Nigerian girls in midwifery; he sent his daughter to England to train as a midwife, and also financed the nursing education of a number of Nigerian ladies in the United Kingdom. ${ }^{41}$

Oguntola Sapara is best remembered by some of his relations for his special interest in West African traditional medicine. During the influenza epidemic of 1918, he popularized the use of a decoction of the leaves of Rauwolfia vomica as a febrifuge and an anticonvulsant. ${ }^{78}$ During his professional life, he expended time and money to make a rational and scientific study of herbal medicine. Some of his medicinal preparations were patented and are still marketed today by reputable firms in 


\section{A. Adeloye}

Nigeria. ${ }^{79}$ Unfortunately, the only records which he left of his experience with herbal medicine were the scanty, sometimes misleading "casual information to friends and colleagues, and his own irregular jottings". ${ }^{80} \mathrm{Dr}$. J. C. Vaughan, when attempting to collate the works of Sapara, lamented this great hiatus and commented "a record of cases treated by Sapara with native plants and his observation thereon would have been a wonderful heritage to students of medicine". ${ }^{80}$

It was not surprising that many honours came to Sapara. In June 1923, King George V awarded him the Imperial Service Order with special reference to his smallpox activities. ${ }^{81}$ Three months later, His Highness, the Alake of Abeokuta made him the Honorary Consulting Physician to the Egba Native Administration. ${ }^{82}$ Early in 1924, in an impressive ceremony, the Owa of Ijeshaland, the paramount ruler of the home of the Saparas, decorated Sapara with the insignia of Bashemi, a chieftaincy title, in special recognition of his contributions to medicine. ${ }^{41}$ The latter ceremony was one of the most auspicious events in the career of Sapara, who, for years, had yearned to return to his home of origin. His long-cherished dream had come true.

\section{CONCLUSION}

The impact of Nigerian pioneer doctors on modern medicine in West Africa went beyond their times; some of their ideals and optimism still linger on today. Horton, Johnson and Randle supported their life-long interest in medicine by philanthropic bequests to science. Randle willed his medical and scientific books and journals to Fourah Bay College, Sierra Leone, and some present-day Nigerian doctors have been beneficiaries of his undergraduate medical scholarships. Unfortunately, incalculable changes in the value of money created difficulties for the implementation of some of these donations. Thus, Horton's dreams of a medical college disappeared with the collapse of his financial investments shortly after his death. At Fourah Bay College, now the University of Sierra Leone, the "chair of science" provided by Obadiah Johnson, and the two Randle professorships are still waiting for their first occupants. ${ }^{41}$ The annual salary of three hundred pounds sterling provided by John Randle for his professorships has to mature enough to entice a professor.

These pioneer doctors envisaged gains of substantial therapeutic value from herbal medicine if only the latter were approached by modern medical men with scientific objectivity. African traditional herbal medicine can make contributions to therapeutics. Some African governments have arranged specific programmes of organized research in African traditional medicine. ${ }^{83}$ In Nigeria, the University of Ife is the centre of such a scheme. However, recently at the Department of Surgery, University of Ibadan, encouraging results came from the researches of Durodola and Ngu who extracted an anti-tumour agent from a local plant used for treating tumours by some Nigerian herbalists. ${ }^{84,85}$ This is only a beginning. With diligence, astuteness, and time, research in West African traditional medicine may unearth such therapeutic gems that could justify the famous words of Pliny: "Out of Africa always something new". ${ }^{88}$

\section{ACKNOWLEDGEMENT}

This paper is dedicated to the late Dr. Evan A. Shanu, a Nigerian medical practitioner, and a good friend. This is to acknowledge my debt of gratitude for his wealth of information about our heritage and his liberal advice and encouragement, all of which made this work possible. 


\section{Some early Nigerian doctors}

\section{REFERENCES}

1. R. Schram, A history of the Nigerian health services, Ibadan University Press, 1971, p. 64.

2. R. M. Smart, Sub-librarian, University of St. Andrews, Scotland: correspondence of 17 May 1971.

3. G. Shepperson, 'An early African graduate', Univ. Edinb. Gaz., 1962, 32: 23-26.

4. L. C. Gwam, Great Nigerians, 1st series, Lagos, Daily Times Press, 1967, p. 26.

5. P.R.O., C.O. 147, 65, Moloney to Lord Knutsford on Death of Adeola, a hospital patient, 1888.

6. M. C. F. Easmon, 'Sierra Leone doctors', Sierra Leone Studies, new series (Journal of the Sierra Leone Society), 1956, 6: 81-96.

7. Daily Times, Nigeria, 17 April 1940.

8. C. E. Maguire, Lagos annual reports, Medical Department, 1899. The Adahunse, a traditional medicine man among the Yorubas of Nigeria is regarded as an alienist. $\mathrm{He}$ is credited with the ability to cure mental and psychiatric disorders by using his occult power (see ref. 9).

9. Samuel Johnson, History of the Yorubas from the earliest times to the beginning of the British Protectorate, ed. Obadiah Johnson, London, Routledge \& Kegan Paul, 1921 (2nd ed. 1966), p. 121.

10. C. Fyfe, A history of Sierra Leone, London, Oxford University Press, 1962, p. 295.

11. P.R.O.,C.O. 96, 45, Bird to Duke of Newcastle, 20 December 1859.

12. J. F. A. Ajayi, Christian missions in Nigeria, 1841-1891: the making of a new elite, London, Longmans, 1965, pp. 161-162.

13. CMS (Yoruba) 1/1/2, 1861-1869. Harrison to CMS Committee, Salisbury Square, London, 4 November 1861.

14. CMS (Yoruba) 1/1/6, 1882-1886. Lang to Mann, 23 June 1882.

15. Lagos Observer, 19 June 1884.

16. Nigerian National Archives, Ibadan, C.S.O. 1 February 1963, Macgregor to Chamberlain, 21 November 1900.

17. O. Obasa, Lagos annual reports, Medical Department, 1902.

18. Herbert Macaulay, 'Nigerian Public Affairs. Comments on the views of Dr. John Randle', Lagos, 24 October 1922.

19. Nigerian Pioneer, 2 November 1923.

20. James Africanus Beale Horton, Letters on the political condition of the Gold Coast since the exchange of territory between the English and the Dutch Governments on January 1, 1868, together with a short account of the Ashantee War, 1862-4, and the Awoonah War, 1866, 2nd ed., with a new introduction by E. A. Ayandele, London, Cass, 1870, p. 7.

21. CMS C.A. 1/0/117-120. Jelf on Horton, 3 November 1858.

22. F. Baker, 'The two Sylviuses. An historical study', Bull. Johns Hopk. Hosp., 1909, 20: 329-339.

23. Lagos Times, 10 January 1883.

24. D. Nicol, James Africanus Beale Horton: the dawn of nationalism in modern Africa, London, Longmans, 1969, p. 12.

25. J. A. B. Horton, 'On the medical Topography of the West Coast of Africa, with sketches of its botany', M.D. thesis University of Edinburgh, March 1859.

26. D. Daiches, Robert Louis Stevenson, New York, Dell, 1959, p. 8.

27. Op. cit. (ref. 21) Horton's 'Treatise on tropical diseases', 10 April 1861.

28. J. A. B. Horton, Physical and medical climate and meteorology of the West Coast of Africa, London, Churchill, 1867, pp. 82-94.

29. F. N. L. Poynter and K. D. Keele, A short history of medicine, London, Mills and Boon, 1961, pp. 54-55.

30. J. A. B. Horton, Guinea-worm or Dracunculus: its symptoms and progress, causes, pathological anatomy, results and radical cure, London, Churchill, 1868, pp. 48-50.

31. J. A. B. Horton, The diseases of tropical climates and their treatment, London, Churchill, 1874, pp. 477-498. 


\section{A. Adeloye}

32. A. S. Sagoe, 'The tropical splenomegaly syndrome in Ibadan', Ph.D. thesis, Ibadan, Nigeria, June 1971.

33. E. J. Watson-Williams and N. C. Allan, 'Idiopathic tropical splenomagaly syndrome in Ibadan', Br. med. J., 1968, 4: 793.

34. P. C. Stuiver, J. L. Ziegler, J. B. Wood, R. H. Morrow and M. S. R. Hutt, 'Clinical trial of malaria. Prophylaxis in tropical splenomegaly syndrome', ibid., 1971, 1: 426-429.

35. M. N. Lowenthal, E. C. O'Riordan and M. S. R. Hutt, 'Tropical Splenomegaly Syndrome in Zambia: Further observations and effects of cycloguanil and proguanil' ibid., 1961, i: 429- 432.

36. Op. cit. (ref. 31 ), pp. 520-539.

37. F. I. D. Konotey-Ahulu, Editorial comment in Ghana med. J., 1968, 7: 118-119.

38. A. Adeloye, 'Sickle-cell anaemia', Br. med. J., 1973, ii, 304-305.

39. J. A. B. Horton, West African countries and peoples, London, W. J. Johnson, 1868, pp. 46-50.

40. T. J. Thompson, The jubilee and centenary volume of Fourah Bay College, Freetown, Sierra Leone, 1930, pp. 54-56.

41. A. Adeloye, African pioneers of modern medicine, Nigerian doctors of the nineteenth century, in press.

42. Editorial on Obadiah Johnson, The Nigerian Pioneer, 17 September 1920.

43. P.R.O. C.O. 147, 115, McCallum to Chamberlain, 13 July 1897.

44. T. A. J. Ogunbiyi, 'Memorial service of Obadiah Johnson', The Nigerian Pioneer, 1 October 1920.

45. Obadiah Johnson, 'An essay on West African therapeutics', M.D. thesis, University of Edinburgh, 1889.

46. G. A. Bender and R. A. Thom, Great Moments in Medicine, Detroit, Parke-Davis, 1961, p. 16.

47. P. P. S. Nylander, 'Twinning in West Africa,'Wld med. J., 1967, $14: 178$.

48. P. P. S. Nylander, 'The frequency of twinning in a rural community in Western Nigeria'. Ann. hum. Genet., 1969, 33: 41.

49. Ladislas Segy, 'The Yoruba Ibeji Statute', Acta Trop., 1970, 27: 97-145.

50. D. M. McFarlan, Calabar. The Church of Scotland Mission, 1846-1946, London, Nelson, 1946, pp. 92-93.

51. Nigerian Spectator, 3 March 1928.

52. Personal Communication with Jack Romanes Adewale Randle, Lagos, 12 September 1971.

53. P.R.O., C.O. 147, 73, Jeans to Under-Secretary of State, 16 May 1890.

54. Nigerian Gazette, No. 19, 30 December 1893, p. 605.

55. 'How Queen Victoria adopted a black girl', The Drum, August 1971.

56. Daily Service, Nigeria, 4 February 1956.

57. Lagos Weekly Times, 22 November 1890.

58. P.R.O., C.O. 147, 85, Carter to Lord Knutsford, 7 July 1892.

59. J. Randle, 'The treatment of guinea worm', Lancet, 1894, i: 143.

60. J. Randle, 'Cancer among the African Creoles', Br. med. J., 1910, ii: 1193-1194.

61. T. Sollman, A manual of pharmacology, London, W. B. Saunders, 1957, pp. 166-167.

62. W. Renner, 'The spread of cancer among the descendants of the liberated Africans or Creoles of Sierra Leone', Br. med. J., 1910, ii: 587-589.

63. Op. cit. (ref. 10), p. 423.

64. 'Cancer-rates in Blacks and Whites', Lancet, 1973, i: 708.

65. K. Akinsemoyin, 'Personalities of Old Lagos', Lagos Weekend, 31 October 1969, pp. 6, 11.

66. Durham University Calendar, 1893.

67. P.R.O., C.O. 147, 30. Rayner to Chamberlain 9 March 1898.

68. Nigerian Pioneer, 10 December 1926. 


\section{Some early Nigerian doctors}

69. C. J. Lumpkin, Lagos annual reports, Medical Report, Ereko Dispensary, 1901-1902.

70. Durham University Calendar, 1898-9.

71. Nigerian Daily Telegraph, 5 June 1935.

72. O. Adewoye, 'Sapara Williams: the lawyer and the public servant', J. hist. Soc. Nigeria, 1971, 6: 47-65.

73. J. M. Dalziel and O. Sapara, 'Leaflet on tuberculosis', Lagos Weekly Record, 6 September 1919.

74. Nigerian Pioneer, 21 November 1924.

75. O. Sapara, 'Report to the Colonial Government on smallpox epidemic in Yoruba country', Lagos, 1 September 1909.

76. A. Deniga, African leaders, Lagos, African Church Press, 1919.

77. Nigerian Pioneer, 8 October 1926.

78. J. M. Dalziel, The useful plants of west tropical Africa, London, Crown Agents, 1973, p. 377.

79. A. Adeloye, 'West African therapeutics as seen by some Nigerian pioneers of modern medicine', J. med. pharm. Marketing, Nigeria, 1972, i: no. 2., 7-10.

80. J. C. Vaughan, 'Native medicine', The Service, 14 September 1935, $20-21$.

81. Nigerian Pioneer, 22 June 1923.

82. Ibid., 5 October 1923.

83. Peggy Cole, Daily Times, Nigeria, 17 November 1971, pp. 14-15.

84. J. I. Durodola, and V. A. Ngu, 'A new cytotoxic substance from Nigerian plant. Its effect on sarcoma 180 in mice', J. Niger. med. Ass., 1968, 1: 14-23.

85. J. I. Durodola, 'Studies on certain Nigerian medicinal plants with potential antineoplastic activity'. Ph.D. thesis, Ibadan University, October 1972, 174 pp.

86. Editorial, 'Out of Africa always', West Afr. med. J., 1967, 16: 187. 